\title{
Udział społeczno-kulturalnych i pedagogicznych wydawnictw periodycznych w wypracowywaniu i upowszechnianiu ideologii wychowawczej sanacji
}

Ważnym środkiem przekazywania informacji i kształtowania opinii publicznej w Polsce okresu międzywojennego była prasa.

Myśl ideologiczna i pedagogiczna ruchu piłsudczykowskiego znajdowała swoje odzwierciedlenie nie tylko w oficjalnych dokumentach, ale również w znacznej mierze w publicystyce ukazującej się na łamach prasy związanej z obozem sanacyjnym. Z tych też względów uważam, że materiały tego rodzaju zasługują na szczególną uwagę. Publicystyka bowiem pozwala systematycznie i wielostronnie prześledzić proces kształtowania się, dojrzewania w toku dyskusji oraz formułowania poglądów na różne, często węzłowe kwestie związane z ideologią i myślą pedagogiczną.

W badaniach opublikowanych w mojej pracy pt. Wychowanie państwowe jako ideologia wychowawcza sanacji. Kształtowanie i upowszechnianie w periodycznych wydawnictwach społeczno-kulturalnych i pedagogicznych (Bydgoszcz 1994) poddano szczegółowej analizie wydawnictwa periodyczne Ministerstwa Wyznań Religijnych i Oświecenia Publicznego, w tym głównie "Oświatę i Wychowanie” (1929-1939) oraz „Poradnik w Sprawach Nauczania i Wychowania oraz Administracji w Szkołach Ogólnokształcących i Seminariach Nauczycielskich” (1929_ 1939), a także pisma subwencjonowane przez MWRiOP: „Kulturę Pedagogiczną” (1933) i „Wiedzę i Życie” (1931-1939). Obok nich zanalizowano grupę czasopism ideowo związanych z obozem piłsudczykowskim: „Drogę” (1922-1937), „Pion” (1933-1939) i „Zaczyn” (1936-1939). Osobną uwagę, ze względu na szczególną rolę jaką odegrały w wypracowywaniu i upowszechnianiu ideologii wychowawczej sanacji, poświęcono działalności wydawniczej stowarzyszenia Zrąb, w tym kwartalnikowi o tej samej nazwie, który ukazywał się w latach 1930-1936 oraz „Rodzinie i Dziecku” (1935-1939) i miesięcznikowi „Dom i Szkoła Powszechna”

* Prof. dr hab., prof. zw. UG, Kierownik Zakładu Diagnostyki Edukacyjnej, Instytut Pedagogiki, Wydział Nauk Społecznych, Uniwersytet Gdański, 80-952 Gdańsk, ul. Bażyńskiego 4. 
(1939). W sumie poddano prasoznawczej i merytorycznej analizie około trzydzieści tytułów.

Analizowane pisma reprezentowały bardzo zróżnicowany poziom i zainteresowania tematyczne. Jednak całość problematyki ideowej i pedagogicznej występującej na ich łamach można skoncentrować wokół następujących zagadnień:

- formułowania konstytutywnych założeń filozoficznych i ideologicznych ruchu piłsudczykowskiego oraz wypracowania w oparciu o nie naczelnych wartości teleologii wychowawczej sanacji;

- ustalania na podstawie wytycznych programu politycznego stosunku wychowania państwowego do podstawowych problemów społeczno-politycznych ówczesnej Polski, w tym m.in. mniejszości narodowych, kwestii światopoglądowych i wychowania religijnego;

- wypracowania teoretycznych podstaw pedagogicznych i socjologicznych doktryny wychowawczej sanacji, obejmujących przede wszystkim terminologię, cele, zadania, zakres, treści oraz relacje między wychowaniem państwowym a innymi doktrynami pedagogicznymi, popularnymi w okresie II Rzeczypospolitej;

- zajmowania się stroną realizacyjną procesu wychowania, w tym przede wszystkim opracowanie zespołu metod, środków i form oddziaływań wychowawczych;

- analizy społecznych czynników i warunków powodzenia wychowania państwowego;

- popularyzacji idei wychowania państwowego poprzez przetransponowanie głównych przesłanek teoretycznych owej koncepcji na język praktyki pedagogicznej.

W tym właśnie kręgu mieściły się kwestie realizacji celów wychowania państwowego w instytucjach oświatowych, organizacjach młodzieżowych i wychowaniu rodzinnym oraz opracowanie założeń nowych programów szkolnych.

W zakresie wypracowania filozoficznych i ideologicznych podstaw doktryny wychowawczej sanacji szczególną rolę odegrały publikacje zamieszczane w „Drodze” i „Pionie”. Począwszy od 1937 r. w związku z likwidacją „Drogi”, będącej głównym organem teoretycznym obozu piłsudczykowskiego, podobną rolę starał się odgrywać, z mniejszym jednak powodzeniem, tygodnik „Zaczyn” związany z Obozem Zjednoczenia Narodowego (OZN).

Socjologiczne i pedagogiczne problemy wychowania państwowego znajdowały swoje odzwierciedlenie w opracowaniach naukowych, prezentowanych przede wszystkim na łamach „Kultury Pedagogicznej”, „Wiedzy i Życia”, a także w wielu pracach zamieszczanych w „Zrębie” oraz "Oświacie i Wychowaniu”. Autorzy publikowanych tam rozpraw poddawali analizie przede wszystkim sporne kwestie terminologiczne, socjologiczne interpretacje naczelnych pojęć i wartości wychowania państwowego, problemy pedeutologiczne, a także zagadnienia dotyczące teleologii doktryny pedagogicznej sanacji oraz jej stosunku do pedagogiki narodowej i katolickiej.

Wypracowaniem, w oparciu o tworzony niekiedy również przez siebie program polityczny, stosunku wychowania państwowego do problemu mniejszości 
narodowych oraz społecznej doktryny Kościoła katolickiego i wychowania religijnego zajmowały się głównie ośrodki ideowe i redakcje „Drogi”, „Pionu”, „Zrębu” oraz „Rodziny i Dziecka”. Publicyści zanalizowanych tu pism sanacyjnych zgodnie wypowiadali się za rzeczywistym równouprawnieniem politycznym mniejszości narodowych w Polsce i występowali jednocześnie przeciwko tendencjom ich asymilacji. W wychowaniu państwowym młodzieży narodowości niepolskiej akcentowano przede wszystkim poważną rolę oddziaływania kultury polskiej poprzez przedmioty nauczania szkolnego, z poszanowaniem kultury rodzimej uczniów. Podkreślano też potrzebę kształtowania w świadomości wychowanków poczucia solidaryzmu wszystkich grup narodowościowych jako drogi do wytworzenia postawy patriotyzmu państwowego, niezależnej od uczucia polskiego patriotyzmu narodowego. Rzeczywista jednak polityka władz państwowych wobec mniejszości narodowych często odbiegała od postulatów formułowanych w pismach obozu rządowego.

Bardziej złożony był stosunek publicystów i pedagogów sanacyjnych do problemów światopoglądowych oraz Kościoła katolickiego, jego doktryny wychowawczej. Publicyści analizowanych pism wyrażali najczęściej niechętny stosunek do instytucji Kościoła i kleru katolickiego. Formułowali również wiele postulatów zmierzających do umniejszenia pozycji Kościoła w życiu publicznym i w szkolnictwie. Redakcje „Drogi” i „Pionu” wypowiadały się w wielu publikacjach wyraźnie negatywnie wobec włączenia w zakres doktryny pedagogicznej sanacji treści wychowania religijnego. Podkreślano w tym przypadku m.in. rozbieżność rozumianych transcendentalnie ideałów państwa i Kościoła, a w związku z tym celów oraz założeń wychowania państwowego i religijnego. Mniej jednoznacznie stanowisko w tej kwestii zajmowała redakcja „Zrębu”, która mimo odnotowywania na swych łamach artykułów polemicznych, raczej przychylała się do uwzględnienia w wychowaniu państwowym postulatów pedagogiki katolickiej. Bez zastrzeżeń, natomiast, do końca 1937 r. propagowaniem idei pedagogiki religijnej, zgodnie zresztą ze zmianą dotychczas lansowanego ideału wychowawczego, zajmowała się redakcja „Rodziny i Dziecka”.

Czołowe periodyki społeczno-kulturalne i pedagogiczne obozu sanacyjnego poprzez swoją publicystykę wyznaczały także kierunki oraz szczegółowe wytyczne polityki oświatowej państwa. Wysuwane i uzasadniane na łamach czasopism postulaty dotyczące głównie zmiany ustaw „O ustroju szkolnictwa” i „Szkołach akademickich" doczekały się pełnej realizacji w przygotowanych przez resort oświaty aktach ustawodawczych z 1932 i 1933 r. Po likwidacji „Drogi” i „Zrębu” ambicje w zakresie współuczestnictwa w kształtowaniu polityki oświatowej państwa przejawiała grupa ideowa "Zaczynu”.

Wskazane tu grupy ideowe i periodyki obozu sanacyjnego nie były oczywiście jedynymi ośrodkami wypracowywania doktryny pedagogicznej obozu rządowego. Znaczącą rolę w tym zakresie odegrało Ministerstwo WRiOP, gdzie w różnych komisjach opracowywano poszczególne aspekty teorii wychowania państwowego, programy nauczania i wychowania oraz akty normatywne regulujące ustrój szkolny. Ministerstwo prowadziło także na szeroką skalę działalność popularyzatorską przede wszystkim poprzez formy kursowe, mające na celu zapoznanie kadr kie- 
rowniczych i poszczególnych grup nauczycielskich z założeniami nowej doktryny pedagogicznej. Należy jednak podkreślić, iż prawie dwa lata przed wprowadzeniem przez Ministerstwo WRiOP reformy szkolnej na łamach kwartalnika „Zrąb” przygotowano i wszechstronnie omawiano wytyczne nowych programów i podręczników szkolnych oraz ogłoszono w 1930 r. memoriał organizacji Zrąb zawierający projekt zmiany programów nauczania dla szkół powszechnych i niższych gimnazjów państwowych. Postulaty te również znalazły swoje odzwierciedlenie w opracowanych przez komisje ministerialne nowych programach nauczania i wychowania. Dzięki inicjatywie stowarzyszenia i przy jego wydatnym poparciu została opracowana ustawa o szkolnictwie wyższym. Znaczący był również, w szczególności w latach 1931-1934, wpływ Zrębu na politykę kadrową i obsadzanie kluczowych stanowisk w resorcie oświaty.

Periodyki pedagogiczne, w tym przede wszystkim „Oświata i Wychowanie”, "Zrąb”, „Rodzina i Dziecko”, „Dzienniki Urzędowe” KOS oraz niektóre nauczycielskie pisma związkowe, aktywnie uczestniczyły w przetransponowaniu głównych przesłanek teoretycznych wychowania państwowego na język praktyki pedagogicznej. Nawiązując głównie do zasad „nowego wychowania”, szeroko omawiano i wypracowywano, inspirując niekiedy eksperymenty pedagogiczne, metody, środki, a także formy oddziaływań wychowawczych. Często upowszechniano także doświadczenia wychowawcze szkół i nauczycieli. Redakcje wymienionych pism pedagogicznych tworzyły tym samym ogólną metodykę wychowania państwowego.

Publicystyka pedagogiczna miała również swój udział w dziedzinie określenia warunków realizacji celów doktryny pedagogicznej sanacji w instytucjach oświatowych, organizacjach młodzieżowych i w wychowaniu rodzinnym oraz współpracy wychowawczej rodziców uczniów z nauczycielami. Także w tym zakresie pisma pedagogiczne z powodzeniem podjęły się opracowania modelowych rozwiązań. Popularyzacja idei wychowania państwowego we wszystkich zanalizowanych pismach miała na celu wywołanie w świadomości czytelników, w szczególności nauczycieli i rodziców uczniów, zrozumienia dla ideologii wychowawczej sanacji, aktywnego włączenia się w realizację celów wychowania państwowego oraz emocjonalnego związania ich z obozem rządowym. Ważną rolę w tym zakresie odegrały dzienniki sanacyjne, przede wszystkim „Epoka” i „Gazeta Polska” oraz organ Związku Strzeleckiego - miesięcznik „Praca Strzelecka”. Na łamach tego ostatniego pisma, oprócz szerokiego propagowania ideałów i celów wychowania państwowego, wypracowano oryginalną metodykę wychowania obywatelskiego, dostosowaną do charakteru organizacji oraz form jej działalności.

Istotne dla oceny wskazanych tu wydawnictw periodycznych jest zagadnienie skuteczności ich oddziaływania. W tym przypadku należy podkreślić, iż były to czołowe organy prasowe obozu rządowego, będące jednocześnie ważnymi ośrodkami opiniotwórczymi. Mimo stosunkowo niskiego ich nakładu, który sięgał najczęściej około 2000 egzemplarzy, adresatami publicystyki i rozpraw o charakterze programowym lub naukowym, zamieszczonych w tych periodykach, byli często wysocy rangą urzędnicy państwowi i działacze polityczni, którzy także niejednokrotnie korzystali z ich łamów jako autorzy wypowiedzi prasowych. 
Wielość tytułów oraz ich nakłady wskazują także na dość szeroki krąg odbiorców w środowiskach nauczycielskich. Autorami zamieszczonych tam artykułów byli czołowi ideolodzy i teoretycy wychowania państwowego, m.in.: Sławomir Czerwiński, Janusz Jędrzejewicz, Adam Skwarczyński, Jan Stanisław Bystroń, Jerzy Ostrowski, Hanna Pohoska i Aleksander Hertz. Wobec słabego rozwoju innych środków przekazu rola prasy w okresie międzywojennym była nie do przecenienia. Grupy ideowe wydające analizowane tu periodyki stanowiły ważne ośrodki kształtowania zarówno bieżącej, jak i długofalowej myśli ideowo-politycznej obozu rządowego. Wysoki poziom intelektualny prezentowany przez większość wskazywanych tu czasopism, a także widoczne zaangażowanie emocjonalne znakomitej większości autorów wskazuje na autentyczne zainteresowanie, a wręcz popularność, jaką cieszyło się wówczas wychowanie państwowe. Bardzo ważnym kryterium oceny skuteczności oddziaływania zanalizowanych czasopism był fakt, że postulaty formułowane na ich łamach znalazły swoje odzwierciedlenie w założeniach ewoluującej ideologii wychowawczej sanacji. Dlatego też można sformułować wniosek stwierdzający istotny udział sanacyjnych wydawnictw periodycznych w wypracowaniu i upowszechnianiu polityki oświatowej i ideologii wychowawczej zarówno w jej części teleologicznej, jak również technologii (metodyki) pedagogicznej oraz projektowania systemu wychowawczego. 